Canadian Journal of Fisheries and Aquatic Sciences

Canadian Science Publishing Journal canadien des sciences halieutiques et aquatiques

\title{
Increased relative abundance of colonial scaled chrysophytes since pre-industrial times in minimally- disturbed lakes from the Experimental Lakes Area, Ontario
}

\begin{tabular}{|r|l|}
\hline Journal: & Canadian Journal of Fisheries and Aquatic Sciences \\
\hline Manuscript ID & cjfas-2017-0074.R3 \\
\hline Manuscript Type: & Article \\
\hline Date Submitted by the Author: & 09-Nov-2017 \\
\hline Complete List of Authors: & $\begin{array}{l}\text { Mushet, Graham; Queen's University, Biology } \\
\text { Flear, Karlee; Queen's University, Biology } \\
\text { Wiltse, Brendan; Ausable River Association } \\
\text { Paterson, Andrew; Ontario Ministry of the Environment, Dorset } \\
\text { Environmental Science Centre } \\
\text { Cumming, Brian; Queen's University, Biology }\end{array}$ \\
\hline $\begin{array}{r}\text { Is the invited manuscript for } \\
\text { consideration in a Special } \\
\text { Issue? : }\end{array}$ & N/A \\
\hline Keyword: & $\begin{array}{l}\text { LAKES < Environment/Habitat, CLIMATE CHANGE < General, } \\
\text { PALEOLIMNOLOGY < General, COLONIAL CHRYSOPHYTES }\end{array}$ \\
\hline \multicolumn{2}{|c}{} \\
\hline
\end{tabular}




\section{Increased relative abundance of colonial scaled chrysophytes since pre-industrial times in minimally-disturbed lakes from the Experimental Lakes Area, Ontario}

List of Authors: Graham R. Mushet, Karlee Flear, Brendan Wiltse, Andrew M. Paterson, and Brian F. Cumming

Graham R. Mushet, Paleoecological Environmental Assessment and Research Laboratory, Dept. of Biology, Queen's University, 116 Barrie Street, Kingston, Ontario, Canada, K7L 3J9, gmushet1@gmail.com

Karlee Flear, Paleoecological Environmental Assessment and Research Laboratory, Dept. of Biology, Queen’s University, 116 Barrie Street, Kingston, Ontario, Canada, K7L 3J9, karleeflear@gmail.com

Brendan Wiltse, Ausable River Association, PO Box 8, Wilmington, New York 12983, wiltseb@gmail.com

Andrew M. Paterson, Dorset Environmental Science Centre, Ontario Ministry of Environment and Climate Change, 1026 Bellwood Acres Road, Dorset, Ontario, Canada, P0A 1E0, andrew.paterson@ontario.ca

Brian F. Cumming, Paleoecological Environmental Assessment and Research Laboratory, Dept. of Biology, Queen's University, 116 Barrie Street, Kingston, Ontario, Canada, K7L 3J9. cummingb@queensu.ca 
Corresponding author: Graham R. Mushet, M.Sc.

Mail: Paleoecological Environmental Assessment and Research Laboratory, Dept. of Biology,

Queen's University, Kingston, Ontario, Canada, 116 Barrie Street, K7L 3J9

Telephone: 16135391649 Email: gmushet1@gmail.com 


\begin{abstract}
A top-bottom paleolimnological analysis of 30 undisturbed lakes in the Experimental Lakes Area (ELA) in northwest Ontario showed marked increases in the relative abundance of colonial scaled-chrysophyte taxa in most lakes since preindustrial times. The increase in abundance of colonial taxa was primarily driven by Synura sphagnicola in small, high-nutrient, and warm lakes. The colonial taxa Synura petersenii and Synura echinulata also increased in the deeper study lakes. Detailed analysis of sediment cores from six lakes revealed that these changes occurred in the early-to-mid 1900's. Based on the modern distribution of scaled chrysophytes relative to lake physicochemical data, we propose multiple processes that may be contributing to these changes, such as changes in lake thermal properties and historical changes in the flux of important particles and solutes to lakes. Additional mechanisms that may contribute to the observed changes are discussed, including trophic interactions and changes in limnetic $p \mathrm{CO}_{2}$. Because the ELA is relatively undisturbed, our findings provide important information on the drivers responsible for increases in colonial chrysophyte abundance which have been documented in studies of lakes in central Ontario and northeast United States.
\end{abstract}




\section{Introduction}

Canada's boreal region represents an important component of the freshwater biome, containing an estimated $800,000 \mathrm{~km}^{2}$ of surface freshwater (Cheskey et al. 2011). These freshwater systems have cultural, ecological, and economic significance as they are sources of drinking water, support a diverse range of species, and are used for oil extraction, agricultural practices, and generating hydroelectric power. However, the integrity of boreal lakes is potentially threatened by a number of different stressors such as direct and indirect effects from acid and nutrient deposition, logging, mining and watershed development (Watmough et al. 2005; Schindler and Lee 2010). Further, the boreal biome is predicted to be one of the biomes most affected by climate over the next century (Ruckstuhl et al. 2008). However, because environmental stressors can co-occur and operate on different spatial and temporal scales it is often difficult to quantify the relative importance of climate changes on limnological properties (Adrian et al. 2009).

Boreal lakes are especially sensitive to temperature changes and large-scale changes in climate (Schindler et al. 1996). This is largely a consequence of their oligotrophic and circumneutral nature, which makes their physical, chemical and biological processes responsive to atmospheric changes (Xenopolous and Schindler 2001). Climate change in the boreal region has contributed to complex changes in lakes, including changes in water temperature, ice-on and ice-off periods, thermal stability, transparency, nutrient cycling, and chemical inputs (Fee et al. 1996; Schindler et al. 1996; Rühland et al. 2008; Hadley et al. 2014). Such changes to the physical and chemical properties of lakes can influence the composition and abundance of phytoplankton species and other lake biota (Findlay et al. 2001; Winder and Schindler 2004; Adrian et al. 2009). This has 
been noted particularly by changes in diatom assemblages, with increases in Discostella spp. attributed to recent climate change (Rühland et al. 2015). However, changes in the thermal characteristics of lakes in response to warming have also been noted to affect other important algal groups, such as the scaled chrysophytes (Nicholls 1995).

Scaled chrysophytes are often an important component of the algal assemblage in lacustrine systems, particularly in lakes that are slightly acidic, cool, and have low nutrients (Sandgren 1988; Siver 1995). Some of the most commonly occurring scaled chrysophytes belong to the genera Synura and Mallomonas, with Synura being comprised of colonial taxa, and Mallomonas being comprised of unicellular taxa. Both Synura and Mallomonas are strict photoautotrophs. Historically, the siliceous remains of chrysophytes that are morphologically distinct between taxa have been used to reconstruct long-term changes in lake $\mathrm{pH}$ in regions that experienced high levels of acid deposition (e.g. Cumming et al. 1994). However, a number of limnological and paleolimnological studies have documented recent increases in the relative abundance of colonial scaled chrysophytes since pre-industrial times in lakes in north-temperate and boreal regions including the Muskoka-Haliburton region (Paterson et al. 2004; Paterson et al. 2008; Hyatt et al. 2010), reference lakes in the Adirondacks (Arseneau et al. 2016), and smaller increases in eastern Canada (Ginn et al. 2010). Because increases in the relative abundance of colonial chrysophytes appear to be widespread and unrelated to historical changes in $\mathrm{pH}$ in these regions, regional climate change has been hypothesized as a possible primary or partial driver of these changes through its effects on water column stability. However, such studies have taken place where additional stressors may be interacting with climate, thereby making it difficult to identify the relative role of climate as a driver of change (Paterson et al. 2004; Arseneau et al. 2016). 
The Experimental Lakes Area (ELA) in northwest Ontario provides the opportunity to isolate the impacts of long-term changes in atmospheric and hydrological forcings on freshwater ecosystems because it has remained undisturbed by urban and industrial activity, is subject to only low levels of acid and nutrient deposition in comparison to other regions in eastern North America (Watmough et al. 2005) and has experienced minimal amounts of forest harvesting in its catchments (Schindler et al. 1991; Jeziorski et al. 2014). Here, we use a top-bottom paleolimnological approach to investigate changes in the scaled-chrysophyte assemblages in the minimally-impacted boreal lakes of the ELA between pre-industrial and modern sediments. The top-bottom method is a useful technique for rapidly assessing limnological change from two defined periods across a large number of lakes (Cumming et al. 1992a). We combine the topbottom analysis with detailed paleolimnological data from sediment cores from six ELA study lakes to identify the timing of change in the scaled-chrysophyte assemblages. Specifically, these data are used to address three questions: (1) what are the modern day scaled-chrysophyte assemblages and how are they related to lake physical-chemical characteristics, (2) how have scaled-chrysophyte assemblages changed from pre-industrial to modern times in minimallyimpacted ELA lakes and, (3) when did scaled-chrysophyte assemblages begin to change?

\section{Materials and Methods}

Regional site description

The 37 study lakes are located in the Experimental Lakes Area (ELA) 50 km East of Kenora (Fig. 1), an area of northwest Ontario with a low population density and no urban or industrial 
development. The ELA is situated on Precambrian Shield bedrock which is dominated by pink granodiorite (Granite), although in some areas this rock is overlain by thin glacial drift (Brunskill and Schindler 1971). The watersheds in the ELA are characterized by thin and discontinuous soils $(<1 \mathrm{~m})$ that consist primarily of organic Brunisols (Schindler et al. 1996), and are dominated by stands of Picea mariana (black spruce) and Pinus banksiana (jack pine). Soils and bedrock are typically covered in Sphagnum dominated mosses which range from $>0.5 \mathrm{~m}$ in thickness in low-lying areas, to absent on hilltops (Schindler et al. 1996). The climate in the region is continental, with warm-to-hot summers and cold winters, and relatively short autumn and spring seasons. Mean annual air temperature and precipitation recorded in nearby Kenora ( $\sim 50 \mathrm{~km}$ ), Ontario are $3.3^{\circ} \mathrm{C}$ and $794 \mathrm{~mm}$, respectively, and mean summer (June - August) and winter (December - February) temperatures are $18.6^{\circ} \mathrm{C}$ and $-13.6^{\circ} \mathrm{C}$, respectively (means from 1980 to 2015). The Kenora climate records indicate the region has experienced a $\sim 1.3^{\circ} \mathrm{C}$ increase in mean annual air temperature (MAAT) over the last $\sim 100$ years, with a more pronounced increase beginning in the mid-1970's (Fig. S1). The increasing trend in MAAT has been shown to be significant since the early 1900's (Laird et al. 2012). Although climate records are available from the ELA, they are short in comparison to the Kenora records as they don't begin until the late 1960's when the ELA was established. However, there is a high degree of correlation for both temperature and precipitation between Kenora and the ELA (Parker et al. 2009), suggesting that the Kenora records can represent climate variability in the ELA. 
Water sampling and study lake description

Detailed water chemistry data and multivariate analysis of lake physicochemical characteristics can be found in Enache et al. (2011). Briefly, water samples were collected at the time of sediment core collection and analyzed at the Ontario Ministry of the Environment and Climate Change (MOECC) Dorset Environmental Science Centre using standard protocols (Ontario Ministry of the Environment 1983). Lake-water surface temperature, $\mathrm{pH}$, and conductivity were measured in the field. Lake $p \mathrm{CO}_{2}$ was estimated from temperature, $\mathrm{pH}$, and alkalinity using standard relations for inorganic carbon equilibria and dissociation and Henry's Law constants from Eby (2004) (Table S1).

The 37 study lakes from which sediment cores were collected are small $(<100$ ha with the exception of Lake 468), relatively shallow (mean $Z_{\max }=9.3 \mathrm{~m}$, median $=8.5 \mathrm{~m}$, range $=2-30$ m), oligotrophic (mean total phosphorus $=6.9 \mu \mathrm{g} \mathrm{L}^{-1}$; median $=5.1 \mu \mathrm{g} \mathrm{L}^{-1}$; range $=1-21 \mu \mathrm{g} \mathrm{L}^{-1}$ ), acidic to circumneutral (mean $\mathrm{pH}=6.7$, median $\mathrm{pH}=6.7$, range $=5.4-7.2$ ), and have moderate to high concentrations of DOC (mean DOC $=7.3 \mathrm{mg} \mathrm{L}^{-1}$, median $=6.9 \mathrm{mg} \mathrm{L}^{-1}$, range $=3-15 \mathrm{mg}$ $\mathrm{L}^{-1}$ ). Of the study lakes, three have experienced manipulations. In 1993, northern pike (Esox lucius) were introduced to Lake 110, and from 1979-1986 Lake 114 was manipulated for epilimnetic acidification. Several experiments have occurred in Lake 226, including epilimnetic fertilization from 1973 to 1980, addition of radioisotope tracers from 1977-1978 and metals in 1987, and lowering of water levels from 1995 to 1997. These lakes were retained in our topbottom study, but are differentiated in the analysis to allow comparison with all other unmanipulated lakes. 
Sediment core collection and sample processing

Details regarding sediment core collection and core chronologies can be found in Enache et al. (2011). Briefly, sediment cores were collected from the deepest basin of each lake in June 2006, using a gravity corer with an internal diameter of $7.62 \mathrm{~cm}$ (Glew et al. 2001). Cores were sectioned at $0.5-\mathrm{cm}$ intervals and samples were placed into individual Whirlpak ${ }^{\circledR}$ bags. The sediments were transported to Queen's University (Kingston, Ontario) where they were stored in a dark cold room $\left(4^{\circ} \mathrm{C}\right)$ until processed for microfossil analysis.

All sediment cores were analyzed using the top-bottom technique, to provide a rapid assessment of how scaled-chrysophyte assemblages have changed across the ELA since pre-industrial times. In this investigation, the $0-0.5 \mathrm{~cm}$ interval (top) represented the modern scaled-chrysophyte species assemblage, and the 20-20.5 cm interval (bottom) represented the pre-industrial species assemblage. Although all sediment cores used in the top-bottom analysis were not individually radiometrically dated, detailed ${ }^{210} \mathrm{~Pb}$ chronologies of six sediment cores in this study (see below), and ${ }^{210} \mathrm{~Pb}$ chronologies of cores from an additional five lakes in the ELA indicates that supported (background) ${ }^{210} \mathrm{~Pb}$ is consistently reached by a core depth of $20 \mathrm{~cm}$ (Lakes 468 and 256 from Wiltse 2014, and Lakes 164, 378, and 383 from Jeziorski et al. 2014). These ${ }^{210} \mathrm{~Pb}$ chronologies represent lakes that range in nutrients (TP) from $1.2-9.7 \mu \mathrm{g} \mathrm{L}^{-1}$ and depths of $5-25 \mathrm{~m}$, which is representative of the lake types in this analysis and also indicates lakes with varying rates of sedimentation were considered when selecting the $20-20.5 \mathrm{~cm}$ interval as pre-industrial. This is also consistent with age-depth relationships in sediment cores from other northwest Ontario lakes 
(Paterson et al. 2002). Therefore, we are confident that a core depth of $20 \mathrm{~cm}$ is sufficient to represent pre-industrial sediments.

To prepare samples for scaled-chrysophyte analysis, $\sim 0.2-0.3 \mathrm{~g}$ of wet sediment was subsampled into a 20-mL glass vial for each sample. A 50:50 molar mixture of concentrated sulfuric and nitric acid was added and heated in a hot water bath at $\sim 75^{\circ} \mathrm{C}$ for $7-8$ hrs to remove organic matter. Samples were further processed and mounted onto glass slides, as outlined in Enache et al. (2011). All samples from the six sediment cores selected for detailed chrysophyte analysis were spiked with a known volume and concentration $\left(2 \times 10^{7}\right.$ spheres $\left.\mathrm{mL}^{-1}\right)$ of microspheres to allow calculation of scale concentrations. Chrysophyte scales were identified and enumerated using a Leica DMRB microscope and a 100x oil immersion objective (numerical aperature $=1.3$ ) using differential interference contrast optics at 1000x magnification. For calculations of relative abundance, 300 scales were counted when possible. However, because some samples had low concentrations and diversity of chrysophyte scales, counts to only 100 scales were possible in some samples. A sample was deemed to have scale concentrations too low to count if the minimum count of 100 scales was not possible without multiple slides and days of counting effort. Taxonomic identification of scales was based on standardized taxonomic literature including Nicholls and Gerrath (1985) and Siver (1991a), and an unpublished reference collection at the Paleoecological Environmental Assessment and Research Laboratory (PEARL). Small-sized Mallomonas scales that could not be identified to species level under a light microscope were grouped into the category Mallomonas 'small' (Cumming et al. 1992b; Paterson et al. 2004). Two morphologically distinct forms of Mallomonas punctifera scales were observed and thus were enumerated separately as M. punctifera (small) and M. punctifera 
(large). M. punctifera (small) scales were approximately 2 × $3 \mu \mathrm{m}$ whereas the M. punctifera (large) scales were approximately $4 \times 6 \mu \mathrm{m}$. The taxonomic literature supports the fact that scale size for this taxon can vary both within and among regions, indicating scale size may be a reflection of different genetic strains or environmental conditions (Siver 1991a).

Chronologies of detailed cores

Sediment cores from six lakes (Lakes 99, 127, 129, 224, 373, 377) were selected for detailed paleolimnological analysis to determine the timing of changes in scaled-chrysophyte assemblages across the ELA. Age-depth relationships for these cores were generated using ${ }^{210} \mathrm{~Pb}$ radioisotopic techniques. Sediments were analyzed for ${ }^{210} \mathrm{~Pb}$ activities at $0.5-\mathrm{cm}$ intervals via gamma spectroscopy following procedures similar to Schelske et al. (1994). Prior to analysis, wet sediment samples were freeze-dried and approximately $0.5 \mathrm{~g}$ of dry sediment from each interval was transferred into a plastic tube. The tubes were then sealed with 2-Ton Epoxy and allowed to equilibrate $\left({ }^{214} \mathrm{Bi}\right.$ to $\left.{ }^{226} \mathrm{Ra}\right)$ for at least two weeks. Radioactive decay was measured for 80,000 s using an EG\&G $\operatorname{Ortec}^{\circledR}$ germanium (Gr) crystal well-detector at PEARL at Queen's University, Kingston. Chronologies were calculated based on ${ }^{210} \mathrm{~Pb}$ activities and cumulative dry mass using the Constant Rate of Supply (CRS) model (Appleby and Oldfield 1978) and the computer program developed by Binford (1990). Based on the age-depth model generated by the CRS model, a $2^{\text {nd }}$ order polynomial was used to extrapolate dates to $\sim 1800$. 
Numerical analysis

Redundancy analysis (RDA) was used to determine the relationship between the modern scaledchrysophyte assemblages and lake physical-chemical characteristics. RDA is an ordination technique that constrains the response variables to the explanatory data, and assumes a linear species-environment response model (ter Braak and Prentice 1988). RDA was performed using forward selection to identify the minimum set of environmental variables that could explain significant $(p<0.05)$ variation in the species assemblage data, using the software CANOCO v. 5.0. (ter Braak and Šmilauer 2012). Variables identified as significant during the forward selection process were included as active variables in the ordination, with the remaining variables plotted passively. Prior to analysis, species that did not reach $2 \%$ relative abundance in the surface sediments of at least two lakes were excluded from the analysis to reduce the influence of rare species. The species relative abundance data were also square-root transformed to reduce the influence of the dominant taxa Mallomonas duerrschmidtiae and Mallomonas crassisquama. Prior to the analysis, a correlation matrix was run on the lake chemical data to identify highly collinear $(r>0.85)$ variables to exclude from the analysis (most of the major ions including $\mathrm{Mg}, \mathrm{K}, \mathrm{Na}$, and $\mathrm{Ca}$, and true colour and $\mathrm{NH}_{4}{ }^{+} / \mathrm{NH}_{3}$ were also excluded). All 13 remaining environmental variables with the exception of temperature were log-transformed prior to the analysis to improve normality.

Principal components analysis (PCA), a linear unconstrained ordination method was used to summarize the trajectory of change in scaled-chrysophyte species composition from preindustrial to modern sediments. Prior to each PCA, relative abundance data were square-root 
transformed, and species that did not reach $2 \%$ relative abundance in at least two samples were eliminated from the dataset to reduce the influence of rare taxa. PCA was performed using the software CANOCO v. 5.0. (ter Braak and Šmilauer 2012). To test for a significant difference between the modern and pre-industrial scaled-chrysophyte assemblages in the study lakes, an analysis of similarity (ANOSIM) was performed. ANOSIM is a non-parametric multivariate test used to examine a similarity matrix comparing the samples from two a-priori defined groups. ANOSIM was based on a Bray-Curtis similarity using square-root transformed relative abundance data (Clarke 1993), and run using the vegan package (Oksanen et al. 2010) in R ( $R$ Core Development Team 2010). A Similarities Percentages test (SIMPER) was run to identify which taxa made an important contribution to the overall difference in chrysophyte assemblage composition between pre-industrial and modern sediments. SIMPER was also run using the vegan package (Oksanen et al. 2010) in R (R Core Development Team 2010).

Principal curve scores (PrC scores) were used to summarize overall scaled-chrysophyte assemblage change through time in each of the six cores that were selected for detailed analysis. Principal curves are an ordination-based method that fit a smooth curve through multidimensional data, and can be considered a form of nonlinear principal components analysis (De'ath 1999). Principal curves were used because first axis scores of other methods of dimension reduction (e.g. PCA) often do not capture single dominant gradients which are common in time-series of assemblage changes (Simpson and Birks 2012). For all cores, PCA axis-1 scores were used as starting points for principal curve fitting. Methods outlined in Simpson and Birks (2012) were followed, allowing the complexity of smoothing splines to vary, and using Generalized Cross Validation (GCV) to determine the spline degrees of freedom. PrC 
scores and the $\%$ abundance of colonial taxa through time were shown together to help assess the degree to which changes in $\%$ colonial taxa influenced the overall chrysophyte assemblage. Lastly, a stratigraphically constrained cluster analysis (CONISS) was performed on the relative abundance in each of the six detailed cores to help identify major periods of similar scaledchrysophyte assemblages. CONISS was performed in Tilia v. 2.02 (Grimm 1987) on square-root transformed species data, using Euclidean distance as a measure of dissimilarity.

\section{Results}

Modern scaled-chrysophyte assemblages (RDA)

Scaled-chrysophyte relative abundance data and associated water chemistry from a total of 32 lakes were included in the RDA, after removing lakes with missing water chemistry data at the time of sediment coring (Lakes 114, 224, 226, 631, 651). This also removed both lakes that have experienced chemical manipulations in the past (Lakes 114 and 226). Twenty-two scaledchrysophyte taxa were identified in the modern sediments, and 16 were retained in the RDA after imposing the $2 \%$ cutoff. The first and second axes of the RDA explained $29 \%$ of the cumulative variation in the modern scaled-chrysophyte assemblages, and the forward selection process determined that only two environmental variables, DOC and surface area (SA), could account for significant variation in the modern scaled-chrysophyte assemblages (at $p<0.05)$ (Fig. 2). Testing the significance of the constrained axes revealed axis- 1 was significant, but axis- 2 was not (at $p$ $<0.05)$. The first axis $(\lambda=0.27)$ separated higher abundances of species with positive loadings including Synura curtispina Asmund, Mallomonas crassisquama (Asmund) Fott, M. elongata 
Reverdin, M. caudata Ivanov, as well as S. petersenii Korshikov to some extent (Fig. 2). These taxa achieved higher abundances in larger, deeper, and higher-pH lakes. This is in contrast to species with negative loadings on RDA axis-one such as $S$. sphagnicola Korshikov, $M$. punctifera (small) Korshikov and Mallomonas cf. M. acaroides, which achieved higher abundances in smaller lakes with higher concentrations of DOC and nutrients (TP). We note that there are two varieties of M. acaroides (M. acaroides Perty emend. Ivanov var. muskokana Nicholls and M. acaroides var. acaroides Perty emend. Iwanoff) which often require electron microscopy to distinguish reliably, and it is therefore difficult to determine which variety is present in the ELA. Although not significant, the second axis $(\lambda=0.02)$ separated a number of additional colonial and unicellular species, although taxa with negative loadings were nearly orthogonal to most environmental variables (Fig. 2).

Top-bottom analysis

In total, 25 lakes had sufficient concentrations of scales in both the top and bottom sediments to enumerate to the species level. However, lakes that had sufficient concentrations of scales for enumeration in the modern sediments only were still retained in the PCA. Together, axis-1 and axis-2 of the PCA explained 55\% of the variation in the modern and pre-industrial scaledchrysophyte species assemblages $\left(\lambda_{1}=0.35, \lambda_{2}=0.20\right)$ (Fig. 3 ). The trajectories from the preindustrial to modern species assemblages were generally consistent in terms of direction for the vast majority of lakes (with the exception of Lake 651), with a trend towards the upper-right quadrant of the ordination (Fig. 3a). Generally, the species vectors indicate this trend represented a decline in the relative importance of unicellular taxa including $M$. duerrschmidtiae, $M$. 
pseudocoronata Prescott, and M. crassisquama from the pre-industrial sediments, and an increase in the relative importance colonial taxa (primarily S. sphagnicola) in the modern sediments (Fig. 3b). The PCA ordination and top-bottom relative abundance diagram also indicated that some additional colonial taxa had higher relative abundance in the modern sediments, particularly S. echinulata and S. petersenii (Fig. 3, Fig. S2). An exception to this trend was the increase in M. punctifera (small), which is a unicellular taxon. M. 'small' spp. and Mallomonas cf. M. acaroides also showed small increases in some of the lakes. Evidence of significant declines in the relative abundance of unicellular taxa and increases in colonial taxa from the pre-industrial to modern sediments was supported by the ANOSIM, which suggested a significant difference in chrysophyte species composition between the two time periods $(R=$ $0.13, p=0.003)$. The low $R$-value is a reflection of low similarity between lakes in each time period (average similarity of modern $=59.7$; average similarity of pre-industrial $=60.1$ ). The average similarity between the tops and bottoms of all lakes was $42.7 \%$, which indicates that the change between the two time periods is greater than the variability in assemblages across lakes within each time step. Increased relative abundance of colonial taxa also was apparent when comparing the $\%$ abundance of colonial taxa between pre-industrial and modern sediments (Fig. 4a). Additionally, the trends in species composition between pre-industrial and modern sediments identified by the PCA were supported by SIMPER analysis and an analysis of the mean \% change of important taxa between the two time periods across all 25 lakes. These analyses indicated changes in species composition between the pre-industrial and modern sediments were primarily driven by declines in $M$. duerrschmidtiae, M. pseudocoronata, and $M$. crassisquama, and increases in the colonial taxa S. sphagnicola, S. echinulata, and S. petersenii (Fig. 4b). 
Detailed scaled-chrysophyte analysis and core chronologies

The six cores that were selected for detailed analysis showed very good $\left(r^{2}>0.9\right)$ first order exponential decay of total ${ }^{210} \mathrm{~Pb}$ activity, indicating strong chronological control (Fig. S3). Further, the estimated chronologies indicate that pre-industrial (pre-1850) sediments are contained in the upper 20 -cm of all cores selected for detailed analysis. Sedimentation rates in all lakes were sufficient to achieve a decadal to sub-decadal temporal resolution, with analysis undertaken at 1-cm intervals for all lakes with the exception of Lake 373, where analysis was undertaken at $0.5-\mathrm{cm}$ intervals.

With the exception of Lake 127, The PrC scores of scaled-chrysophyte assemblages and the change in $\%$ colonial taxa within each of the six cores selected for detailed analysis showed similar patterns (Fig. 5), suggesting that the changes in \% colonials are an important driver of the overall assemblage change. The PrC scores from Lake 127 are likely tracking the increase in $M$. caudata that occur earlier in the time series (Fig. S4). Consistent with the top-bottom analysis, the CONISS identified an initial zone of chrysophyte assemblages dominated by unicellular taxa, followed by a second zone corresponding to the increased relative abundance of colonial taxa in all six lakes (Fig. 5, Fig. S4). These changes in relative abundance coincided with increased absolute concentration of colonial taxa (Fig. S4, S5), supporting the expansion of their population. The detailed assemblage data also indicate that the transitions from the older zone to the more recent zone was also characterized by an increase in M. punctifera (small) in Lakes 129 and 127, and an increase in M. hamata Asmund in Lake 224 (Fig. S4). In general, the transition from the older zone to the more recent zone occurred in the early-to-mid 1900's, with the 
exception of ELA 99 which occurred slightly earlier at the turn of the $20^{\text {th }}$ century (Fig. S4, Fig. 5). The transition from the older to the more recent zone occurred at $\sim 1920$-1930 for lakes 127 and 373, and at 1950 for Lakes 129, 224 and 377.

\section{Discussion}

Modern distribution of scaled chrysophytes

The Redundancy Analysis (RDA) indicated that a number of lake physicochemical characteristics are likely influencing the modern-day scaled-chrysophyte species distributions across the ELA (Fig. 2). In the ELA, S. sphagnicola was the most common colonial taxon in the modern sediments and was associated with smaller and warmer lakes high in DOC and nutrients (TP). This pattern is consistent with the findings of Arseneau et al. (2016), who documented higher abundances of $S$. sphagnicola in shallow higher-DOC lakes, based on the modern sediments collected from 31 reference lakes in the Adirondack Park, NY. Paterson et al. (2001) also recorded higher abundances of $S$. sphagnicola in high-DOC and high-nutrient lakes based on surface sediments collected from 53 lakes in the Muskoka-Haliburton region, Ontario. Historically, S. sphagnicola has been referred to as a potential indicator of humic and highly coloured water bodies (Kristiansen 1986), and as a warm-water taxon observed primarily during the summer months (Cronberg and Kristiansen 1980). Thus, in the ELA the prevalence of $S$. sphagnicola in the modern sediments may be attributed to the high number of small, relatively high DOC lakes that tend to have higher surface temperatures (Fig. 2). 
Lake surface area (SA) was also identified as a significant environmental variable related to scaled chrysophyte distributions in the ELA lakes (Fig. 2). The colonial taxa S. petersenii and $S$. curtispina, and the unicellular taxa M. elongata, M. caudata, and M. crassisquama tended to occur in larger, deeper and more alkaline lakes. Previous studies have documented higher abundances of these colonial taxa in larger and deeper lakes in northeastern USA (Dixit et al. 1999), and Arseneau et al. (2016) also documented higher abundances of S. petersenii in deep alkaline lakes in the Adirondacks. This suggests that in addition to $\mathrm{pH}$, the influence of lake morphometry on the thermal properties of the lakes may be important for these taxa, which is consistent with many colonial chrysophytes forming blooms at or below the thermocline in stratified lakes (Siver 2003). M. elongata and M. caudata have also been found to form metalimnetic blooms (Siver 2003), so it is not surprising to find them in higher abundances in these deep sites.

M. duerrschmidtiae was the most common unicellular taxon in the ELA (Fig. S2), which is consistent with surface-sediment assemblages documented by previous studies in Atlantic Canada (Ginn et al. 2010), the Adirondacks (Cumming et al. 1992b; Arseneau et al. 2016) and northeastern USA (Dixit et al. 1999). Although Cumming et al. (1992b) found that $M$. duerrschmidtiae had an intermediate to large tolerance for $\mathrm{pH}(1 \mathrm{pH}$ unit based on standard deviation) in Adirondack (NY, USA) lakes, it is generally considered to prefer cool, acidic, lownutrient, and softwater lakes. Based on surveys from Connecticut (NY, USA) and Adirondack lakes, Siver (1991a) found that M. duerrschmidtiae had a weighted mean temperature of $12.4^{\circ} \mathrm{C}$ (and occurred mostly during the spring and fall), a weighted mean $\mathrm{pH}$ of 5.76, and was recorded in lakes with phosphorus concentrations mostly between 5 to $10 \mu \mathrm{g} \mathrm{L}^{-1}$. Based on the RDA, $M$. 
duerrschmidtiae was nearly orthogonal to a number of important variables (Fig. 2), making it difficult to assess its distribution in the ELA. However, this is likely due to its pervasiveness across the ELA, which is consistent with the lakes generally being low in nutrients (mean $\mathrm{TP}=$ $6.9 \mu \mathrm{g} \mathrm{L}^{-1}$ ), slightly acidic (mean $\mathrm{pH}=6.7$ ) and having relatively low concentrations of calcium and magnesium (means $=1.8$ and $0.6 \mathrm{mg} \mathrm{L}^{-1}$, respectively) (Enache et al. 2011). We also note that the ubiquitous nature of $M$. duerrschmidtiae in the ELA and in many other regions is not simply an artifact of it being a scale-rich taxon. Based on estimates of the number of siliceous scales per cell for various taxa (Siver 1991b), M. duerrschmidtiae has a low average number of scales per cell (36) in comparison to the 11 other Mallomonas spp. common in the ELA (mean = 73 scales per cell, $\max =$ M. caudata at 160 scales per cell, $\min =$. . punctifera at 27 scales per cell).

Potential drivers of change in scaled-chrysophyte assemblages since pre-industrial times

Our results showed that there has been an expansion of the colonial scaled-chrysophyte population across the ELA since pre-industrial times, and in many systems, this trend was largely driven S. sphagnicola. This consistent pattern in multiple lakes across the undisturbed ELA suggests that a regional forcing mechanism has an important control on scaled-chrysophyte assemblages in the ELA. Such increases in the abundance of colonial taxa have been suggested to occur in part due to increased vertical stability in the water column in response to regional warming (e.g. Ginn et al. 2010; Hyatt et al. 2010; Arseneau et al. 2016). However, in the ELA high abundances of S. sphagnicola in the modern sediments were found in a number of very shallow lakes (those $<4 \mathrm{~m}$ ), suggesting stronger stratification did not lead to the proliferation of 
this taxon. Instead, we suggest that warming surface temperatures in response to warming air temperatures and/or extended periods of elevated winter and spring precipitation through the early-to-mid 1900's may have contributed to the proliferation of S. sphagnicola. However, other metalimnetic chrysophytes increased in the deeper study lakes (primarily S. petersenii and $S$. echinulata), suggesting that stratification phenology may be important for these taxa. Previous work has also suggested that shifts in grazing pressure (Arseneau et al. 2016) and limnetic $p \mathrm{CO}_{2}$ (Wolfe and Siver 2013) may have important controls on chrysophyte assemblages. Based on our data and previous studies in the ELA, there is little evidence to suggest that these are important drivers of the observed increases in colonial taxa. Additional work is required, however, to assess the possible interactive effects of these multiple processes (including those related to changes in temperature and precipitation) that may contribute to changes in chrysophyte species composition.

Low-level acid and nutrient deposition

Historically, shifts in scaled-chrysophyte assemblages have been used to infer declines in lakewater $\mathrm{pH}$ because of their strong species-specific optima and tolerances to $\mathrm{pH}$ (e.g. Cumming et al. 1994). For example, Dixit et al. (1992) was able to track the rapid acidification and subsequent recovery in a number of lakes near Sudbury (Ontario) during the $20^{\text {th }}$ century based on compositional change of the chrysophytes. However, in the ELA, acid deposition is an unlikely driver for the changes in chrysophyte species composition, particularly because it remained unaffected by high levels of sulfate deposition during the 1970's and 1980's unlike many regions in eastern North America (Schindler et al. 1991; Parker et al. 2009). Based on 
1990's deposition data, the ELA received the lowest levels of bulk $\mathrm{SO}_{4}$ deposition $\left(7.32 \mathrm{~kg} \mathrm{ha}^{-1}\right.$ $\left.\mathrm{yr}^{-1}\right)$ and among the lowest levels of $\mathrm{NO}_{3}$ deposition $\left(2.13 \mathrm{~kg} \mathrm{ha}^{-1} \mathrm{yr}^{-1}\right)$ of 12 regions across the northeast U.S. and south-central and southeast Ontario and Quebec (Watmough et al. 2005). These depositional rates do not exceed estimated critical acid deposition loads for soils in the ELA (Watmough et al. 2005). This is also supported by Donahue et al. (1998), who showed that the $\mathrm{pH}$ of unmanipulated ELA Lakes 239 and 224 remained stable throughout the 1980's and 1990's. Even though much of the deposition and lake $\mathrm{pH}$ records represent the post clean air act period, paleo-diatom records from many lakes in the region reveal little to no evidence of historical declines in pH (Paterson et al. 2002; Enache et al. 2011; Wiltse 2014). We also note that the taxon $S$. petersenii increased in a number of our study lakes (Fig. 4b, Fig. S2), a taxon that has a preference for lakes with higher $\mathrm{pH}$ based on the modern-day distribution of scaledchrysophytes (Fig.1).

Recent limnological and paleolimnological studies have also linked the enhanced deposition of inorganic nitrogen $(\mathrm{N})$ derived from global increases in burning of fossil fuels and agricultural activities to nutrient enrichment of freshwater systems, and subsequent changes in lake primary production (Bergström et al. 2005; Saros et al. 2011). Though there is some evidence of recent increases in deposition of inorganic $\mathrm{N}$ at the ELA, it is an unlikely driver of the documented increases in colonial scaled-chrysophyte taxa since pre-industrial times. The timing of the increases in colonial taxa based on detailed analysis of the six cores pre-dates the post $c a .1970$ to 1980 increases in $\mathrm{N}$ deposition in the ELA (Parker et al. 2009; Venkiteswaran et al. 2017). Additionally, our study lakes are P-limited according to both DIN:TP (molar ratio, according to Bergström 2010) and TN:TP (mass ratio) (Table S1) and have sphagnum-conifer dominated 
catchments that are efficient sinks of N (Devito and Dillon 1993), thereby limiting phytoplankton sensitivity to additional inputs of inorganic N. Based on data from three catchments in the ELA, Parker et al. (2009) estimated that ammonium and nitrate retention was $\sim 95 \%$ to $100 \%$. This is in strong contrast to the lakes where inorganic $\mathrm{N}$ deposition has been linked to enhanced phytoplankton production, which are generally characterized by N-limitation and low terrestrial $\mathrm{N}$ saturation thresholds due to little upstream vegetation in the lake catchments (e.g. Saros et al. 2011). Similarly, paleo-diatom records from our study lakes are also not consistent with nutrient enrichment effects (Enache et al. 2011).

\section{Precipitation patterns}

Increases in lake-water DOC concentrations have been documented across North America, which is hypothesized to be in response to recovery from acidic deposition to lake catchments and/or increased precipitation (e.g. Williamson et al. 2015). Additionally, acid deposition can also reduce the flux of phosphorus to lakes (Eimers et al. 2009). However, in the absence of high current and historical acid deposition rates in comparison to other regions in eastern North America, DOC and TP flux to lakes in the ELA is usually related to fluctuations in precipitation and stream flow (Schindler et al. 1996).

The Kenora climate records indicate fluctuations in seasonal and annual precipitation. Particularly noticeable are the increases in winter and spring precipitation beginning in the early 1900's (Fig. S6). Such increases in precipitation could enhance streamflow and the flux of important substances to lakes, including phosphorus (P) and DOC (Dillon and Molot 2005). 
Because the RDA of modern assemblages showed that S. sphagnicola prefers high TP and DOC lakes (Fig. 2), shifts in hydrological conditions and associated export of these solutes/particles may have contributed to their proliferation. We also note that the increased relative abundance of S. sphagnicola in lakes 99, 127, and 129 (Fig. S4) began during these periods of elevated spring and winter precipitation. However, our analysis showed that S. petersenii and S. echinulata also increased in our study lakes (Fig. 4b), and that these taxa were negatively associated with nutrients and DOC in our study lakes (Fig. 2). Therefore, enhanced flux of TP and DOC would, in theory, not provide favourable conditions for their growth. Additionally, increased concentrations of DOC would reduce light availability for these metalimnetic chrysophytes (Healey 1983). This suggests that although the flux nutrients and DOC to lakes may have been important for S. sphagnicola, other long-term forcing mechanisms are also influencing chrysophyte populations in the ELA.

Limnetic $p \mathrm{CO}_{2}$

It has recently been hypothesized that chrysophyte populations may be expanding in many systems in response to increased limnetic $p \mathrm{CO}_{2}$, caused by either enhanced organic matter mineralization and/or re-equilibration with rising atmospheric concentrations of $\mathrm{CO}_{2}$ (Wolfe and Siver 2013). In theory, this could put the chrysophytes at a competitive advantage over algae with which they compete (e.g. diatoms) because chrysophytes do not contain a carbon concentrating mechanism $(\mathrm{CCM})$, relying on direct diffusive entry of $\mathrm{CO}_{2}$ during photosynthesis (Raven et al. 2005). Currently, this hypothesis has only been used to explain historical rises in the importance of chrysophytes as a group (specifically Mallomonas and Synura; Wolfe and 
Siver 2013), likely because genus or species-specific data on inorganic carbon acquisition is lacking. It is therefore difficult to assess whether rising $p \mathrm{CO}_{2}$ would favour colonial over unicellular scaled-chrysophytes. However, under the assumption that lakes which experienced larger increases in colonial chrysophyte populations would have higher modern-day limnetic $p \mathrm{CO}_{2}$, we tested for a relationship between: (1) the \% increase in colonial taxa since preindustrial times and modern $p \mathrm{CO}_{2}$, and (2) the ratio of chrysophyte scales to diatom frustules (Sto-D index) and modern $p \mathrm{CO}_{2}$. These correlation tests did not indicate any relationship between either the $\%$ increase in colonial taxa $(r=0.02, p>0.05)$ or the modern S-to-D index $(r=-0.31$, $p>0.05$ ) and $p \mathrm{CO}_{2}$. We also note that a recent study by Vogt et al. (2017) found no evidence for a linkage between $p \mathrm{CO}_{2}$ gradient and chrysophyte biovolume in a survey of 69 boreal lakes in Canada, although similar to previous work these results are applicable at only a coarse taxonomic scale. Moreover, our study lakes are supersaturated with $\mathrm{CO}_{2}$ (Table S1), potentially limiting chrysophyte response to increased $p \mathrm{CO}_{2}$. Genus and species-specific data on possible differential $p \mathrm{CO}_{2}$ uptake efficiencies between Mallomonas and Synura would be required, however, in order to fully assess if it plays any role in chrysophyte assemblage shifts in our study lakes. Additionally, it is important to acknowledge that the metric we used to quantify chrysophyte abundance (S-to-D index) is a ratio and therefore does not represent absolute abundance, which may make it more difficult to identify relationships with $p \mathrm{CO}_{2}$.

Trophic interactions

Climate change is anticipated to have impacts on zooplankton composition in boreal lakes, so it is important to consider potential impacts on interactions between primary and secondary 
producers. For example, lake warming in response to rising air temperatures may favour smallbodied cladocerans, such as Bosmina spp. (Daufresne et al. 2009). The large, colonial scaled chrysophytes (including S. sphagnicola) are largely inedible to smaller cladocerans, but can be predated upon by larger cladocerans such as Daphnia spp. (Sandgren and Walton 1995). Therefore, warming may reduce grazing pressure on colonial chrysophytes and favour their growth. In the ELA, Jeziorski et al. (2014) recorded increased abundances of Bosmina spp. of $\sim 10 \%$ or more in 5 of 10 study lakes, and concluded that regional warming may have played a role in these changes. One of the cores they selected for detailed Cladocera analysis (Lake 383) indicated that Bosmina spp. began to increase in the early 1900's, which largely coincides with the timing of increased colonial taxa in this study. However, Jeziorski et al. (2014) recorded little to no increase in Bosmina spp. in lakes 93, 99, 110, and 129 from pre-1900 to modern sediments, and these lakes all showed large increases in S. sphagnicola in our top-bottom analysis (Fig. S2). This suggests that in the ELA, colonial scaled chrysophytes are increasing regardless of potential climate-mediated decreases in grazing pressure. This is also in agreement with Paterson et al. (2008), who showed that changes in grazing variables did not have an important control on phytoplankton composition (including the chrysophytes) in six of seven intensely monitored lakes in central Ontario. Despite this, however, it is possible that increases in small-bodied cladocerans may exacerbate increases in colonial chrysophytes under warming conditions.

Lake thermal properties

The Kenora climate records indicate a steady increase in mean annual air temperature since $\sim 1960$, with the earliest changes occurring during the summer months (Fig. S1). Regional 
warming is generally expected to lead to longer ice-free seasons, warmer surface temperatures and potentially enhanced thermal stratification of lakes (Adrian et al. 2009). Meta-analysis of global lake temperature data has shown this to be true, although there is a high degree of spatial variability in lake warming rates between geographic areas (Kraemer et al. 2015; O'Reilly et al. 2015). However, on smaller regional scales lakes have been shown to correlate closely to air temperatures during the open-water season (Adrian et al. 2009; Winslow et al. 2017), though there may be high variability in monthly warming rates. Numerous studies have associated such changes in lake thermal properties with the expansion of colonial chrysophyte populations in other regions (Paterson et al. 2004; Hyatt et al. 2010; Arseneau et al. 2016). This is primarily because the colonial scaled chrysophytes (Synura) possess physiological traits that may provide them with a competitive advantage over the smaller unicellular scaled chrysophytes (Mallomonas) under more stable conditions. These include faster swim velocities and larger migration amplitudes (Sommer 1988), and access to nutrient-rich water in the hypolimnion during stratified periods because colonials tend to form blooms at or below the thermocline (Nicholls 1995; Siver 2003). In the ELA, the proliferation of the colonial taxon S. sphagnicola does not appear to be associated with enhanced thermal stratification as they achieved high abundances in some very shallow lakes. For example, Lake 470 has a depth of only $3 \mathrm{~m}$ yet it had one of the highest abundances of $S$. sphagnicola in the modern sediments $(83 \%)$. This trend was noted in a number of additional shallow lakes with depth $<4 \mathrm{~m}$ (e.g. lakes 115, 131, 149, 384, 436, 438; Fig. S2). Therefore, the increased abundance of S. sphagnicola in shallow lakes may be in response to warmer water temperatures as opposed to enhanced thermal stability. This is also supported by the RDA, as lakes with higher abundances of S. sphagnicola also tended to have higher surface temperature (Fig. 2). Numerous studies have documented S. sphagnicola as a 
warm-water taxon (Cronberg and Kristiansen 1980; Siver and Hamer 1992), and it has been noted as one of the few taxa that has its occurrence restricted to higher temperatures (Kristiansen 1986). The increase in the warm-water unicellular taxon M. punctifera (small) (Siver 1991a) in some study lakes also supports the direct role of temperature as a driver of change (Fig. 4b, Fig. S2). Although there are few published long-term records of lake surface temperatures in the ELA, Wiltse et al. (2016) documented an increase in summer and fall epilimnetic temperatures since the beginning of the record in Lake 224, and in fall epilimnetic temperature in Lake 239. In addition, Guzzo and Blanchfield (2016) showed that the summer period shifted later into the fall based on monitoring data from four lakes, and the average length of the ice-covered season became 19 days shorter over the period 1970 to 2013 in Lake 239. These lines of evidence suggest that lakes in the ELA are indeed responding to long-term atmospheric changes. However, the relative importance of warming as a driver of these changes requires further investigation.

The top-bottom analysis also revealed increases in the colonial taxa $S$. petersenii and $S$. echinulata, but to a smaller degree in comparison to S. sphagnicola (Fig. 4b, Fig. S2). The SIMPER and analysis of the mean \% change across study lakes indicated these were the next two most important colonial taxa contributing to the overall assemblage change (Fig. 4b). The RDA indicated S. echinulata and S. petersenii tended to occur in the deeper study lakes (Fig. 2). This finding is consistent with colonials having a competitive advantage in a more stable water column, as previously proposed. In a paleolimnological study of 30 minimally-impacted lakes in the Adirondacks, NY, Arseneau et al. (2016) documented large increases in colonial taxa from pre-industrial to modern sediments, including S. petersenii and S. echinulata. Their analysis 
revealed a similar separation of these species in relation to lake physicochemical characteristics, and that $S$. petersenii was the most important taxon contributing to the overall assemblage change, followed by $S$. sphagnicola and $S$. echinulata. The similar ecological response between the two regions again provides strong evidence for a regional forcing mechanism. However, in the ELA the importance of S. sphagnicola may be due to the predominance of shallower lakes with higher DOC. Overall, these patterns suggest that: S. sphagnicola does not require thermal stratification to be at a competitive advantage, and that the exact mechanisms driving the expansion of colonial chrysophyte populations over broad spatial scales are modulated by lake type.

The detailed analysis of scaled-chrysophyte assemblages in the sediment cores showed that increases in the abundance of colonial taxa occurred since the late 1800's. For example, CONISS identified the transition from the older to more recent zone (i.e. transition from a Mallomonas dominated assemblage to a Synura dominated assemblage) at 1899 and 1921 for Lakes 99 and 127, respectively. In contrast, this transition occurred much later in lakes 224 and 377, at 1957 and 1954 respectively (Fig. 5). It is possible that the difference in timing may be related to lake morphometry. Lakes 99 and 127 are small $\left(\mathrm{SA}=6.5\right.$ ha and 4.7 ha, respectively) shallow $\left(Z_{\max }=\right.$ $6 \mathrm{~m}$ and $5 \mathrm{~m}$, respectively) lakes, whereas lakes 224 and 377 are larger $(\mathrm{SA}=25.4$ ha and 27.2 ha, respectively) and deeper $\left(Z_{\max }=15 \mathrm{~m}\right.$ and $16 \mathrm{~m}$, respectively). Therefore, the earlier response in the smaller lakes (127 and 99) may be due to the fact that they have a low heat capacity (Wetzel 2001), and may respond more quickly to radiative heat exchange and solar irradiance than larger lakes (Gerten and Adrian 2001). Previous studies have noted the important influence that lake-type has on the synchronicity of physical and biological limnological responses to 
regional forcings (e.g. Arnott et al. 2003). An investigation with detailed paleolimnological data from additional lakes would be required to properly address the relationship between lake morphometry and timing of changes between lakes.

Paleolimnological changes consistent with regional warming have already been documented across the ELA. Enache et al. (2011) analyzed diatom assemblages in the top and bottom (preindstrial) sediments of the same lakes in the top-bottom component of this study, and documented an increase in planktonic diatoms (particularly Discostella stelligera) in over half of the study lakes. Wiltse et al. (2016) suggested that these increases in D. stelligera may be a result of earlier ice off and extended spring mixing times. Detailed diatom analysis in six of these cores revealed that increases in D. stelligera began in the early 1900's (Wiltse 2014), which largely corresponds to the timing of increases in colonial scaled chrysophytes in most of our study lakes (Fig. 5, Fig. S4). Although the suggested mechanisms contributing to increases in the planktonic diatom $D$. stelligera and colonial chrysophytes differ, they are both consequences of rising air temperatures.

\section{Conclusions}

Our paleolimnological analysis of lakes in the Experimental Lakes Area showed that the relative abundance of colonial scaled chrysophytes has increased in many lakes across the region from pre-industrial to modern sediments, and that these changes generally began to occur in the earlyto-mid 1900 's. S. sphagnicola was the main driver of this trend in many shallow lakes, although S. petersenii and S. echinulata also increased in many of the deeper lakes. These patterns are 
consistent with findings from paleolimnological investigations in the Adirondacks and southcentral Ontario suggesting a strong regional control over historical chrysophyte populations. Results from the Redundancy Analysis (RDA) between modern scaled-chrysophyte assemblages and lake physicochemical characteristics indicated that many variables control their populations in the ELA, and that multiple mechanisms could be responsible for the observed changes. We suggest that changes in hydrology and associated flux of important nutrients to lakes, as well as rising lake surface temperatures in response to regional warming may have played a role in the proliferation of $S$. sphagnicola, and that stratification may be important for the colonial taxa that increased in the deeper lakes. In addition, it is possible that other drivers such as declines in grazing pressure and increased limnetic $p \mathrm{CO}_{2}$ may affect chrysophyte assemblages in the ELA, although we found limited evidence here, and further investigation is warranted. Our study provided additional evidence that scaled-chrysophyte populations are undergoing a major reorganization in undisturbed boreal lakes. Future increases in the colonial chrysophytes may have implications for water quality. For example, the colonial taxon $S$. petersenii has been noted to cause taste and odour issues in boreal lakes (Nicholls and Gerrath 1985; Paterson et al. 2004). Therefore, it is important to continue to study and monitor the climatically-sensitive Boreal Shield lakes, particularly those in the ELA that are free of many anthropogenic stressors. Future investigations would benefit from experimental approaches to better understand the relative roles of the different mechanisms that may be contributing to the rise in colonial scaled-chrysophyte taxa. 


\section{Acknowledgements}

We acknowledge the assistance of Christina Clarke, Chris Lorenz, Erin MacMillan, and Shelley Wilkinson for providing assistance with logistics and coring. Funding for analyses and some of the fieldwork was provided by a grant to BFC under the Best in Science program of the Ontario Ministry of the Environment, with additional funding for fieldwork provided by a NSERC Discovery Grant to BFC. 


\section{References}

Adrian, R., O'Reilly, C.M., Zagarese, H., Baines, S.B., Hessen, D.O., Keller, W., Livingstone, D.M., Sommaruga, R., Straile, D., Van Donk, E., Weyhenmeyer, G.A., and Winder, M. 2009. Lakes as sentinels of climate change. Limnol. Oceanogr. 54: 2283-2297.

Appleby, P. G. and Oldfield, F. 1978. The calculation of lead-210 dates assuming a constant rate of supply of unsupported ${ }^{210} \mathrm{~Pb}$ to the sediment. Catena $5: 1-8$.

Arnott, S. E., Keller, B., Dillon, P. J., Yan, N., Paterson, M., and Findlay, D. 2003. Using temporal coherence to determine the response to climate change in Boreal Shield lakes. Environ. Monit. Assess. 88: 365-388. doi: 10.1023/A:1025537628078.

Arseneau, K. M. A., Driscoll, C. T., Cummings, C. M., Pope, G., and Cumming B. F. 2016. Adirondack (NY, USA) reference lakes show a pronounced shift in chrysophyte species composition since ca. 1900. J. Paleolimnol. 56: 349-364. doi:10.1007/s10933-016-99222.

Bergström, A. 2010. The use of TN:TP and DIN:TP ratios as indicators for phytoplankton nutrient limitation in oligotrophic lakes affected by N deposition. Aquat. Sci. 72: 277-281. doi: 10.1007/s00027-010-0132-0. 
Bergström, A-K., Blomqvist, P., and Jansson, M. 2005. Effects of atmospheric nitrogen deposition on nutrient limitation and phytoplankton biomass in unproductive Swedish lakes. Limnol. Oceanogr. 50: 987-994. doi: 10.4319/lo.2005.50.3.0987.

Binford, M.W. 1990. Calculation and uncertainty analysis of ${ }^{210} \mathrm{~Pb}$ dates for PIRLA project lakes sediment cores. J. Paleolimnol. 3: 253-267. doi: 10.1007/BF00219461.

Brunskill, G.J. and Schindler, D.W. 1971. Geography and bathymetry of selected lake basins in the Experimental Lakes Area (ELA), northwestern Ontario. J. Fish. Res. Board Can. 28: 139- 155. doi: 10.1139/f71-028.

Cheskey, E., Wells, J., and Casey-Lefkowitz, S. 2011. Birds at Risk: The importance of Canada's Boreal wetlands and waterways. Natural Resources Defense Council, New York, N.Y.

Clarke, K. R. 1993. Non-parametric multivariate analyses of changes in community structure. Aust. J. Ecol. 18: 117-143. doi: 10.1111/j.1442-9993.1993.tb00438.x.

Cronberg, G., and Kristiansen, J. 1980. Synuraceae and other Chrysophyceae from central Småland, Sweden. Bot. Notiser 133: 595-618.

Cumming, B. F., Smol, J. P., Kingston, J. C., Charles, D. F., Birks, H. J. B., Camburn, K. E., 
Dixit, S. S., Uutala, A. J., and Selle, A. R. 1992a. How much acidification has occurred in Adirondack region lakes (New York, USA) since preindustrial times? Can. J. Fish. Aquat. Sci. 49: 128-141. doi: 10.1139/f92-015.

Cumming, B. F., Smol, J. P., and Birks, H. J. B. 1992b. Scaled chrysophytes (Chrysophyceae and Synurophyceae) from Adirondack drainage lakes and their relationship to environmental variables. J. Phycol. 28: 162-178: doi: 10.1111/j.0022-3646.1992.00162.x.

Cumming, B. F., Davey, K. A., and Smol, J. P. 1994. When did acid-sensitive Adirondack lakes (New York, USA) begin to acidify and are they still acidifying? Can. J. Fish. Aquat. Sci. 51: 1550-1568. doi: 10.1139/f94-154.

Daufresne, M., Lengfellner, K., and Sommer, U. 2009. Global warming benefits the small in aquatic ecosystems. P. Natl. Acad. Sci. USA. 106: 12788-12793. doi: 10.1073/pnas.0902080106.

De'ath, G. 1999. Principal curves: a new technique for indirect and direct gradient analysis. Ecology 80: 2237-2253. doi: 10.1890/0012-9658(1999)080[2237:PCANTF]2.0.CO;2.

Devito, K. J., and Dillon, P. J. 1993. The influence of hydrologic conditions and peat oxia on the phosphorus and nitrogen dynamics of a conifer swamp. Water. Resour. Res. 29: 26752685. doi: 10.1029/93WR00622. 
Dillon, P. J., and Molot, L. A. 2005. Long-term trends in catchment export and lake retention of dissolved organic carbon, dissolved organic nitrogen, total iron, and total phosphorus: The Dorset, Ontario, study, 1978-1998. J. Geophys. Res. 110: G01002. doi: 10.1029/2004JG000003.

Dixit, A. S., Dixit, S. S., and Smol, J. P. 1992. Long-term trends in lake water pH and metal concentrations inferred from diatoms and chrysophytes in three lakes near Sudbury, Ontario. Can J. Fish. Aquat. Sci. 49(S1): 17-24. doi: 10.1139/f92-296.

Dixit, S. S., Dixit, A. S., and Smol, J. P. 1999. Lake sediment chrysophyte scales from the northeastern USA and their relationship to environmental variables. J. Phycol. 35: 903918. doi: 10.1046/j.1529-8817.1999.3550903.x.

Donahue, W. F., Schindler, D. W., Page, S. J., and Stainton, M. P. 1998. Acid-induced changes in DOC quality in an experimental whole-lake manipulation. Environ. Sci. Technol. 32: 2954-2960. doi: 10.1021/es980306u.

Eby, G, N. 2004. Principles of Environmental Geochemistry. Thomson-Brooks/Cole, Pacific Grove, CA.

Eimers, M. C., Watmough, S. A., Paterson, A. M., Dillon, P. J., and Yao H. X. 2009. Long-term declines in phosphorus export from forested catchments in south-central Ontario. Can. J. Fish. Aquat. Sci. 66: 1682-1692. doi: 10.1139/F09-101. 
Enache, M. D., Paterson, A. M., and Cumming, B. F. 2011. Changes in diatom assemblages since pre-industrial times in 40 reference lakes from the Experimental Lakes Area (northwest Ontario, Canada). J. Paleolimnol. 46: 1-15. doi: 10.1007/s10933-011-9504-2.

Fee, E. J., Hecky, S. E., Kasian, S. E., and Cruckshank, D. 1996. Effects of lake size, water clarity, and climatic variability on mixing depths in Canadian shield lakes. Limnol. Oceanogr. 41: 912-920. doi: 10.4319/1o.1996.41.5.0912.

Findlay, D. L., Kasian, S. E. M., Stainton, M. P., Beaty, K., and Lyng, M. 2001. Climatic influences on algal populations of boreal forest lakes in the Experimental Lakes Area. Limnol. Oceanogr. 46: 1784-1793. doi: 10.4319/1o.2001.46.7.1784.

Gerten, D., and Adrian, R. 2001. Differences in the persistency of the North Atlantic Oscillation signal among lakes. Limnol. Oceanogr. 46: 448-455. doi: 10.4319/1o.2001.46.2.0448.

Ginn, B. K., Rate, M., Cumming, B. F., and Smol, J. P. 2010. Ecological distribution of scaledchrysophyte assemblages from the sediments of 54 lakes in Nova Scotia and southern New Brunswick, Canada. J. Paleolimnol. 43:293-308. doi: 10.1007/s10933-009-9332-9.

Glew, J. R., Smol, J. P. \& Last, W. M. 2001. Sediment core collection and extrusion. In Tracking Environmental Change Using Lake Sediments, Vol. 1, Basin Analysis, Coring, and Chronological Techniques. Edited by W. M. Last and Smol J. P. Kluwer Academic Publishers, Dordrecht, 548 pp. 
Grimm, E.C. 1987. CONISS - A Fortran-77 program for strati- graphically constrained cluster analysis by the method of incremental sum of squares. Computers \& Geosciences 13: 1335. doi: $\underline{10.1016 / 0098-3004(87) 90022-7 .}$

Guzzo, M. M., and Blanchfield, P. J. 2016. Climate change alters the quantity and phenology of habitat for lake trout (Salvelinus namaycush) in small Boreal Shield lakes. Can. J. Fish. Aquat. Sci. 74: 871-884. doi: 10.1139/cjfas-2016-0190.

Hadley, K. R., Paterson, A. M., Stainsby, E. A., Michelutti, N., Yao, H., Rusak, J. A., Ingram, R., McConnell, C., and Smol, J. P. 2014. Climate warming alters thermal stability but not stratification phenology in a small north-temperate lake. Hydrol. Process. 28:6309-6319. doi: 10.1002/hyp.10120.

Healey, F. P. 1983. Effect of temperature and light intensity on the growth rate of Synura sphagnicola. J. Plankton. Res. 5: 767-774. doi: 10.1093/plankt/5.5.767.

Hyatt, C. V., Paterson, A. M., Cumming, B. F., and Smol, J. P. 2010. Factors related to regional and temporal variation in the distribution of scaled chrysophytes in north-eastern North America: Evidence from lake sediments. Nova Hedwigia, Beiheft 136: 87-102. doi: $10.1127 / 1438-9134 / 2010 / 0136-0087$.

Jeziorski, A., Paterson, A. M., Watson, I., Cumming, B. F., and Smol, J. P. 2014. The influence of calcium decline and climate change on the cladocerans within low calcium, 
circumneutral lakes of the Experimental Lakes Area. Hydrobiologia 722: 129-142. doi: 10.1007/s10750-013-1691-6.

Kraemer, B. M., Anneville, O., Chandra, S., Dix, M., Kuusisto, E., Livingstone, D. M., Rimmer, A., Schladow, S. G., Silow, E., Sitoki, L. M., Tamatamah, R., Vadeboncoeur, Y., and McIntyre, P. B. 2015. Morphometry and average temperature affect lake stratification responses to climate change. Geophys. Res. Lett. 42: 4981-4988. doi: 10.1002/2015GL064097.

Kristiansen, J. 1986. Silica bearing chrysophytes as environmental indicators. British Phycology Journal 21: 425-436. doi: 10.1080/00071618600650491.

Laird, K. R., Haig, H., Ma, S., Kingsbury, M. V., Brown, T. A., Lewis, C. F. M., Oglesby, R. J., and Cumming, B. F. 2012. Expanded spatial extent of the Medieval Climate Anomaly Revealed in lake-sediment records across the boreal region in northwest Ontario. Glob. Change Biol. 18: 2869-2881. doi: 10.1111/j.1365-2486.2012.02740.x.

Nicholls, K. H. 1995. Chrysophyte blooms in the plankton and neuston of marine and freshwater systems. In Chrysophyte algae: Ecology, phylogeny and development. Edited by Sandgren C. D., Smol J. P., and Kristiansen J. Cambridge University Press, Cambridge, pp 181-213.

Nicholls, K.H. and Gerrath, J.F. 1985. The taxonomy of Synura (Chrysophyceae) in Ontario with 
special reference to taste and odour in water supplies. Can. J. Bot. 63: 1482-1493. doi: $10.1139 / \mathrm{b} 85-205$.

Oksanen, J., Blanchet, F. G., Kindt, R., Legendre, P., O’Hara, R. B., Simpson, G. L., Solymos, P., Stevens, M. H. H., and Wagner, H. 2010. Vegan: Community Ecology Package. R package version 1.17-4. http://CRAN.R-project.org/ package=vegan.

Ontario Ministry of the Environment (1983) Handbook of analytical methods for environmental samples, vol 1 and 2. Laboratory Services Branch, Ontario Ministry of the Environment and Energy, Sudbury, ON.

O’Reilly, C. M., Sharma, S., Gray, D. K., Hampton, S. E., Read, J. S. et al. 2015. Rapid and highly variable warming of lake surface waters around the globe. Geophys. Res. Lett. doi: 10.1002/2015GL066235.

Parker, B.R., Schindler, D.W., Beaty, K.G., Stainton, M.P., and Kasian, S.E.M. 2009. Long-term changes in climate, streamflow, and nutrient budgets for first-order catchments at the Experimental Lakes Area (Ontario, Canada). Can. J. Fish. Aquat. Sci. 66: 1848-1863. doi: $10.1139 / \mathrm{F} 09-149$.

Paterson, A. M., Cumming, B. F., Smol, J. P., and Hall, R. I. 2001. Scaled chrysophytes as indicators of water quality changes since preindustrial times in the Muskoka-Haliburton region, Ontario, Canada. Can. J. Fish. Aquat. Sci. 58: 2468-2481. doi: 10.1139/cjfas-58- 
$12-2468$.

Paterson, A. M., Morimoto, D. S., Cumming, B. F., Smol, J. P., and Szeicz, J. M. 2002. A paleolimnological investigation of the effects of forest fire on lake water quality in northwestern Ontario over the past ca. 150 years. Can. J. Bot. 80: 1329-1336. doi: 10.1139/B02-117.

Paterson, A. M., Cumming, B. F., Smol, J. P., and Hall, R. I. 2004. Marked recent increases of colonial scaled chrysophytes in boreal lakes: implications for the management of taste and odour events. Freshwater Biol. 49:199-207.

Paterson, A. M., Winter, J. G., Nicholls, K. H., Clark, B. J., Ramcharan, C. W., Yan, N. D., and Somers, K. M. 2008. Long-term changes in phytoplankton composition in seven Canadian Shield lakes in response to multiple anthropogenic stressors. Can. J. Fish. Aquat. Sci. 65: 846-861. doi: 10.1139/F08-022.

R Development Core Team. 2010. R: A Language and Environment for Statistical Computing. Vienna, Austria: R Foundation for Statistical Computing. Available online at: http://www.R-project.org/

Raven, J.A., Ball, L.A., Beardall, J., Giordano, M., and Maberly, S.C. 2005. Algae lacking carbon concentrating mechanisms. Can. J. Bot. 83: 879-890. doi: 10.1139/b05-074 
Ruckstuhl, K. E., Johnson, E. A., and Myianishi, K. 2008. The boreal forest and global change. Philos. T. Roy. Soc. B. 363:2245-2249. doi: 10.1098/rstb.2007.2196.

Rühland, K., Paterson, A. M., and Smol, J. P. 2008. Hemispheric-scale patterns of climaterelated shifts in planktonic diatoms from North American and European lakes. Glob. Change Biol. 14: 2740-2754. doi: 10.1111/j.1365-2486.2008.01670.x.

Rühland, K. M., Paterson, A. M., and Smol J. P. 2015. Lake diatom response to warming: reviewing the evidence. J. Paleolimnol. 54: 1-35. doi: 10.1007/s10933-015-9837-3.

Sandgren C. D. 1988. The ecology of Chrysophyte flagellates: their growth and perennation strategies as freshwater phytoplankton. In Growth and Reproductive Strategies of Freshwater Phytoplankton. Edited by C. D. Sandgren. Cambridge University Press, Cambridge, 452 pp.

Sandgren, C.D., Walton, W.E. 1995. The influence of zooplankton herbivory on the biogeography of chrysophyte algae. In Chrysophyte algae: ecology, phylogeny and development. Edited by Sandgren C. D., Smol J. P., and Kristiansen J. Cambridge University Press, Cambridge, pp 269-302.

Saros, J.E., Clow, D.W., Blett, T., and Wolfe, A. P. 2011. Critical nitrogen deposition loads in high- elevation lakes of the western US inferred from paleolimnological records. Water Air Soil Pollut. 216: 193-202. doi: 10.1007/s11270-010-0526-6. 
Schelske, C. L., Peplow, A., Brenner, M. and Spencer, C. N. 1994. Low-background gamma counting: applications for ${ }^{210} \mathrm{~Pb}$ dating of sediments. J. Paleolimnol. 10:115-128. doi: 10.1007/BF00682508.

Schindler, D. W. and Lee, P. G. 2010. Comprehensive conservation planning to protect biodiversity and ecosystem services in Canadian boreal regions under a warming climate and increasing exploitation. Biol. Conserv. 143: 1571-1586. doi: 10.1016/j.biocon.2010.04.003.

Schindler, D.W., Frost, T.M., Mills, K.H., Chang, P.S.S., Davies, I.J., Findlay, L., Malley, D.F., Shearer, J.A., Turner, M.A., Garrison, P.J., Watras, C.J., Webster, K., Gunn, J. M., Brezonik, P.L. and Swenson, W.A. 1991. Comparisons between experimentally- and atmospherically-acidified lakes during stress and recovery. Proceedings Royal Society Edinburgh 97: 193-226.

Schindler, D.W., Bayley, S.E., Parker, B.R., Beaty, K.G., Cruikshank, D.R., Fee, E.J., Schindler, E.U., and Stainton, M.P. 1996. The effects if climate warming on the properties of boreal lakes and streams at the Experimental Lakes Area, northwestern Ontario. Limnol. Oceanogr. 41: 1004-1017. doi: 10.4319/1o.1996.41.5.1004.

Simpson, G. L., and Birks, H. J. B. 2012. Statistical learning in palaeolimnology in Tracking Environmental Change Using Lake Sediments. Edited by H. J. B. Birks, A. L. Lotter, S. Juggins, and J. P. Smol. Springer, Dordrecht. pp. 249-327. 
Siver, P.A. 1991a. The Biology of Mallomonas. Kluwer Academic Publishers, Dordrecht, The Netherlands.

Siver, P. A. 1991b. Implications for improving paleolimnological inference models utilizing scale-bearing siliceous algae: transforming scale counts to cell counts. J. Paleolimnol. 5: 219-225. doi: 10.1007/BF00200346.

Siver, P. A. 1995. The distribution of chrysophytes along environmental gradients: their use as biological indicators. In Chrysophyte Algae: Ecology, Phylogeny and Development. Edited by Sandgren C. D., Smol J. P., and Kristiansen J. Cambridge University Press, Cambridge, 399 pp.

Siver, P. A. 2003. Synurophyte algae. In Fresh- water algae of North America: Ecology and classification. Edited by J. D. Wehr. Academic Press, San Diego, pp 523-558.

Siver, P. A., and Hamer, J. S. 1992. Seasonal periodicity of chrysophyceae and synurophyceae in a small New England lake: implication for paleolimnological research. J. Phycol. 28: 186-198. doi: 10.1111/j.0022-3646.1992.00186.x.

Sommer, U. 1988. Some size relationships in phytoflagellate motility. Hydrobiologia 161:125131. doi: 10.1007/978-94-009-3097-1_10.

ter Braak, C. J. F. \& Šmilauer, P. 2012. CANOCO reference manual and user's guide: software 
for ordination (version 5.0). Microcomputer Power, Ithaca, New York, 496 pp.

ter Braak, C. J. F., and Prentice, I. C. 1988. A theory of gradient analysis. Advances in Ecological Research 34: 235-282.

Venkiteswaran, J. J., Schiff, S. L., Paterson, M. J., Flinn, N. A. P., Shao, H., and Elgood, R. J. 2017. Changing nitrogen deposition with low $\delta^{15} \mathrm{~N}-\mathrm{NH}_{4}{ }^{+}$and $\delta^{15} \mathrm{~N}-\mathrm{NO}_{3}{ }^{-}$values at the Experimental Lakes Area, northwestern Ontario, Canada. Facets 2: 249-266. doi: 10.1139/ facets-2016-0060.

Vogt, R. J., St-Gelais, N. F., Bogard, M. J., Beisner B. E., and del Giorgio, P. A. 2017. Surface water $\mathrm{CO}_{2}$ concentration influences phytoplankton production but not community composition across boreal lakes. Ecol. Lett. 20: 1395-1404. doi: 10.1111/ele.12835.

Watmough, S. A., Aherne, J., Alewell, C., Arp, P., Bailey, S., Clair, T., Dillon, P., Duchesne, L., Eimers, C., Fernandez, I., Foster, N., Thorjorn, L., Mitchell, M., and Page, S. 2005. Sulphate, nitrogen and base cation budgets at 21 forested catchments in Canada, the Unites States and Europe. Environ. Monit. Assess. 109: 1-36. doi: 10.1007/s10661-005$4336-\mathrm{z}$

Wetzel, R.G. 2001. Limnology. Lake and River Ecosystems. Third Ed. Academic Press, San Diego. 
Williamson, C. E., Overholt, E. P., Pilla, R. M., Leach, T. H., Brentrup, J. A., Knoll, L. B., Mette, E. M., and Moeller, R. E. 2015. Ecological consequences of long-term browning in lakes. Sci. Rep. 5, 18666. doi: 10.1038/srep18666.

Wiltse, B. 2014. The response of Discostella species to climate change at the Experimental Lakes Area, Canada. Ph.D. thesis, Queen's University, Kingston, Ontario.

Wiltse, B., Paterson, A. M., Findaly, D. L., and Cumming, B. F. 2016. Seasonal and decadal patterns in Discostella (Bacillariophyceae) species from bi-weekly records of two boreal lakes (Experimental Lakes Area, Ontario, Canada). J. Phyc. 52: 817-826. doi: 10.1111/jpy.12443.

Winder, M., and Schindler, D. W. 2004. Climate change uncouples trophic interactions in an aquatic ecosystem. Ecology 85: 2100-2106. doi: 10.1890/04-0151.

Winslow, L. A., Read, J. S., Hansen, G. J. A., Rose, K. C., and Robertson, D. M. 2017. Seasonality of change: Summer warming rates do not fully represent effects of climate change on lake temperatures. Limnol. Oceanogr. doi: 10.1002/lno.10557.

Wolfe, A. P. and Siver, P. A. 2013. A hypothesis linking chrysophyte microfossils to lake carbon dynamics on ecological and evolutionary timescales. Global Planet. Change 111:189198. doi: 10.1016/j.gloplacha.2013.09.014. 
Xenopolous, M. A., and Schindler, D. W. 2001. The environmental control of near-surface thermoclines in boreal lakes. Ecosystems 4: 699-707. doi: 10.1007/s10021-001-0038-8. 


\section{Figure Captions}

Fig. 1. Location of the 37 study lakes in the Experimental Lakes Area (ELA), Ontario. The inset depicts study location relative to the province of Ontario. Lakes selected for detailed sediment core analysis are indicated in bold italic font.

Fig. 2. Redundancy analysis $(R D A)$ biplot showing the distribution of scaled chrysophyte taxa in the modern sediments of 32 lakes in the Experimental Lakes Area (ELA), with respect to important environmental variables. Lakes with missing modern environmental data were eliminated from this analysis.

Note: $\mathrm{TP}=$ total phosphorus, $\mathrm{DOC}=$ dissolved organic carbon, $\mathrm{TKN}=$ total kjeldahl nitrogen, Temp $=$ surface temperature, $\mathrm{SA}=$ surface area, Cond $=$ conductivity, Sulf $=$ sulfate. All variables are log-transformed with the exception of Temp.

Fig. 3. Principal Components Analysis (PCA) of scaled-chrysophyte assemblages in the modern and pre-industrial sediments of 37 lakes in the Experimental Lakes Area (ELA). (a) site trajectories with respect to scaled-chrysophyte assemblage composition from pre-industrial (open circles) to modern (closed circles) times. In total, 25 lakes had sufficient concentrations in the pre-industrial sediments to reach the minimum scale count. Asterisks indicate lakes that have had experimental manipulations or other disturbances (ELA Lakes 110, 114, and 226). (b) PCA species vectors. 
Fig. 4. Summary figures of the top (modern)-bottom (pre-1900) paleolimnological analysis of 25 lakes in the Experimental Lakes Area (ELA). (a) Relative abundance (\%) of colonial chrysophyte taxa in top (modern) vs. bottom (pre-industrial) sediment samples in the 25 lakes that had sufficient concentrations of chrysophyte scales for enumeration in both the top and bottom samples. The black line represents a 1:1 relationship. Lakes that have been experimentally manipulated in the past are indicated by black dots (ELA Lakes 110, 114, and 226). (b) mean \% change (grey bars) and the SIMPER \% contribution of taxa to the difference between preindustrial and modern assemblage composition in 25 lakes in the ELA (black dots). Only the taxa that made a significant contribution to the difference in assemblage composition between the two periods (as identified by the SIMPER analysis) were included in this analysis. Taxa are listed from left to right in order of maximum mean $\%$ decrease to maximum mean $\%$ increase across the lakes between pre-industrial and modern assemblages.

Fig. 5. Results from the detailed paleolimnological analysis of six lakes in the Experimental Lakes Area (ELA). \% Colonial taxa and PrC scores through time are shown. Zones identified by the CONISS are indicated by the dashed lines. 


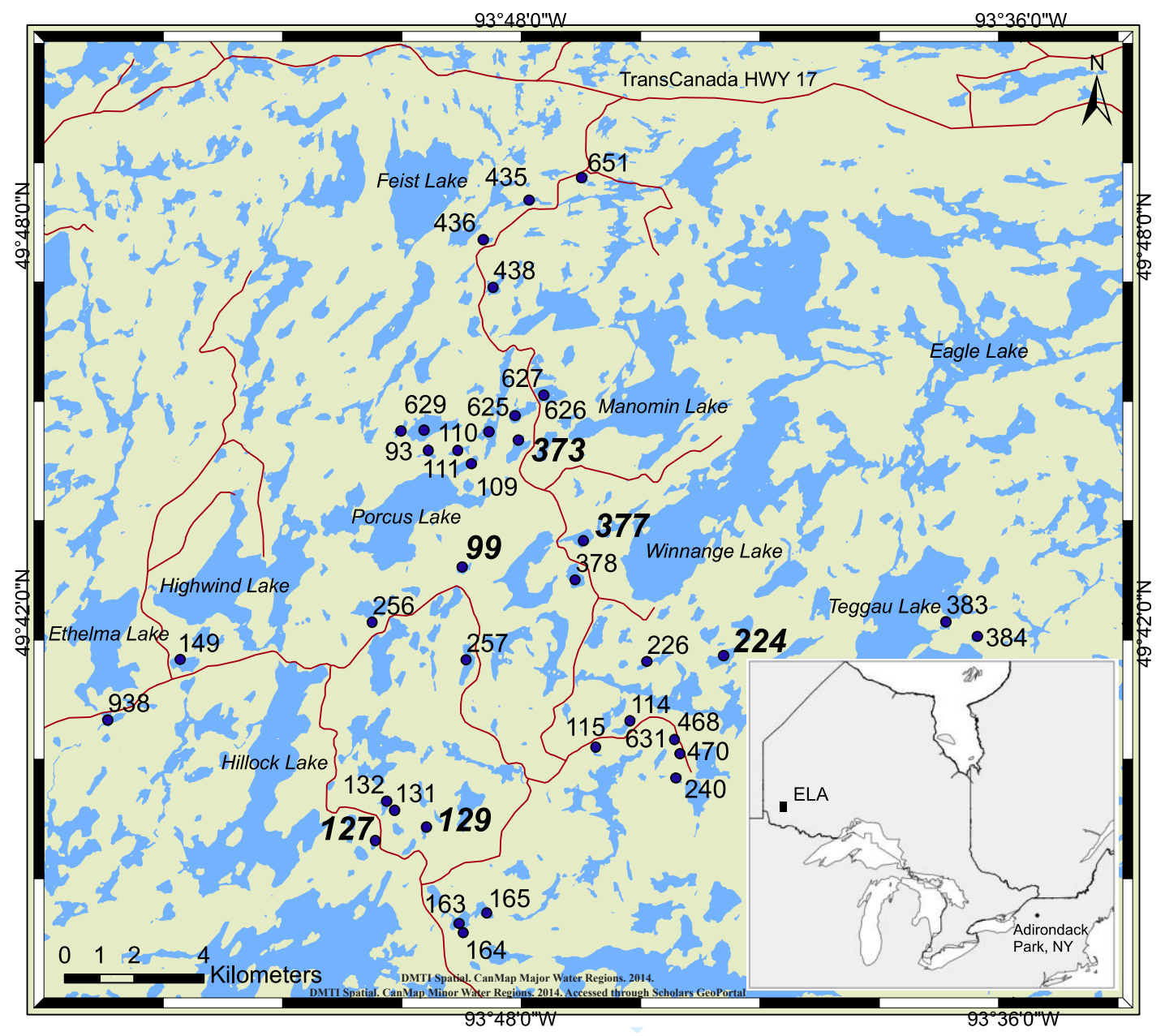

Fig. 1. 


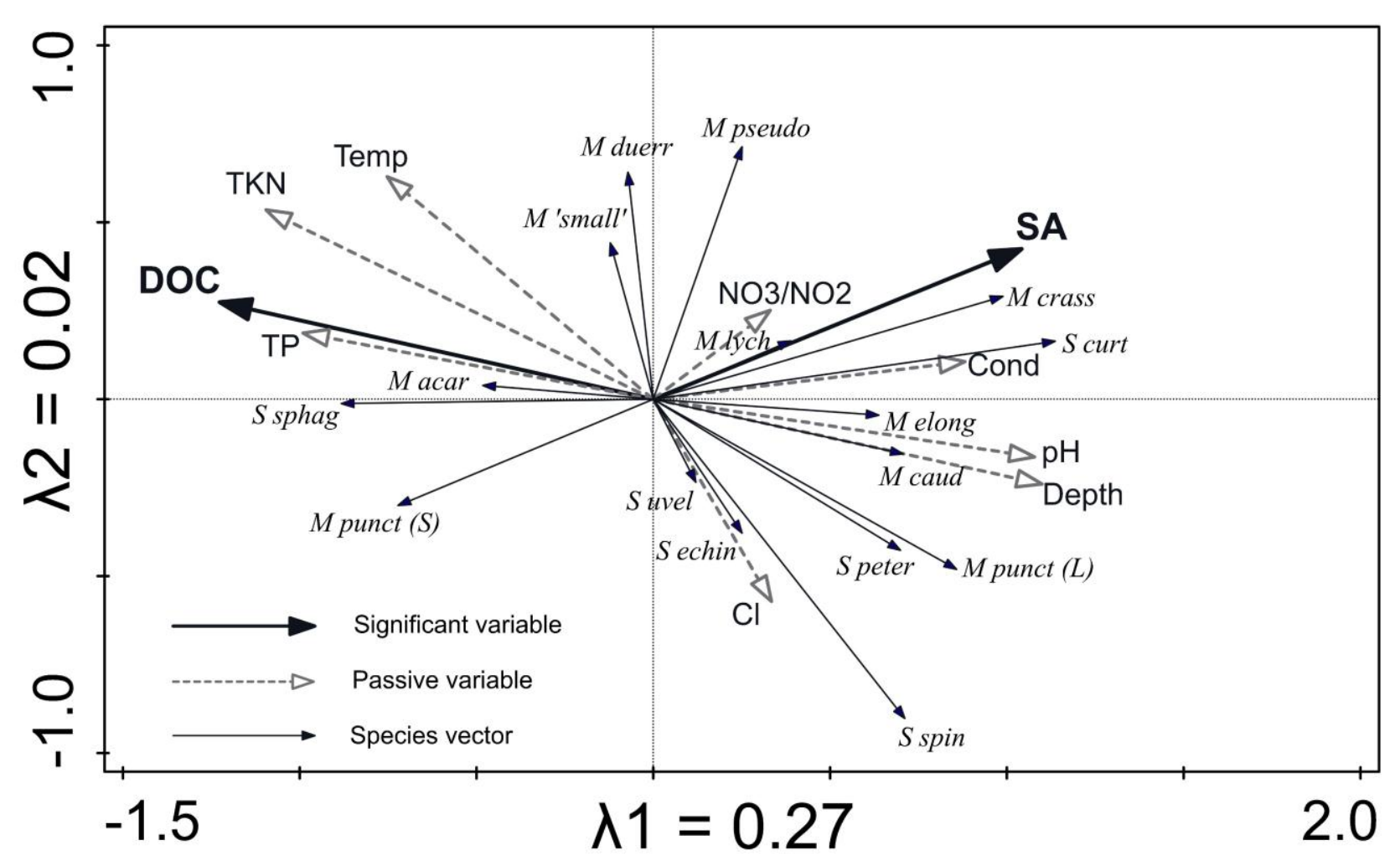

Fig. 2. 

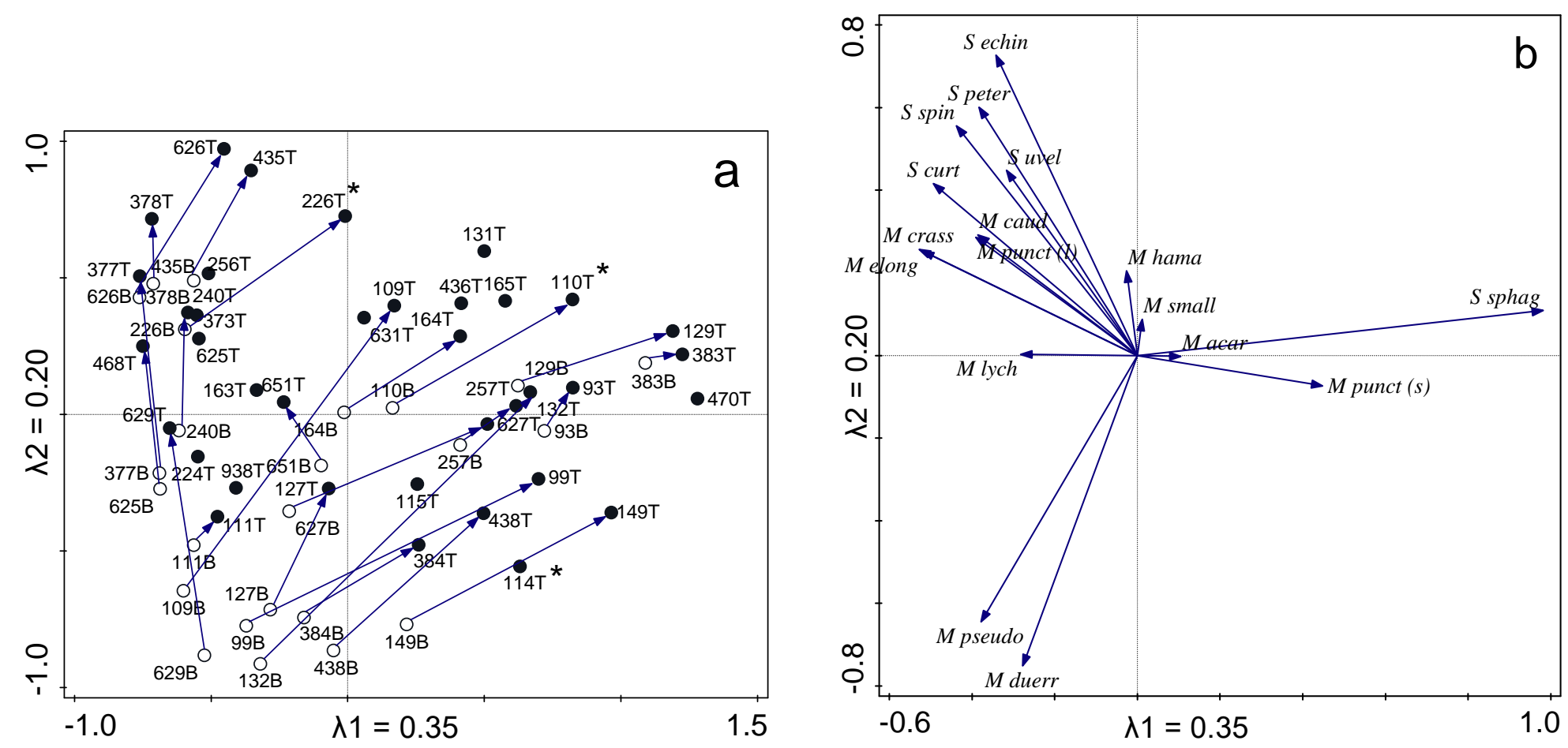

Fig. 3. 

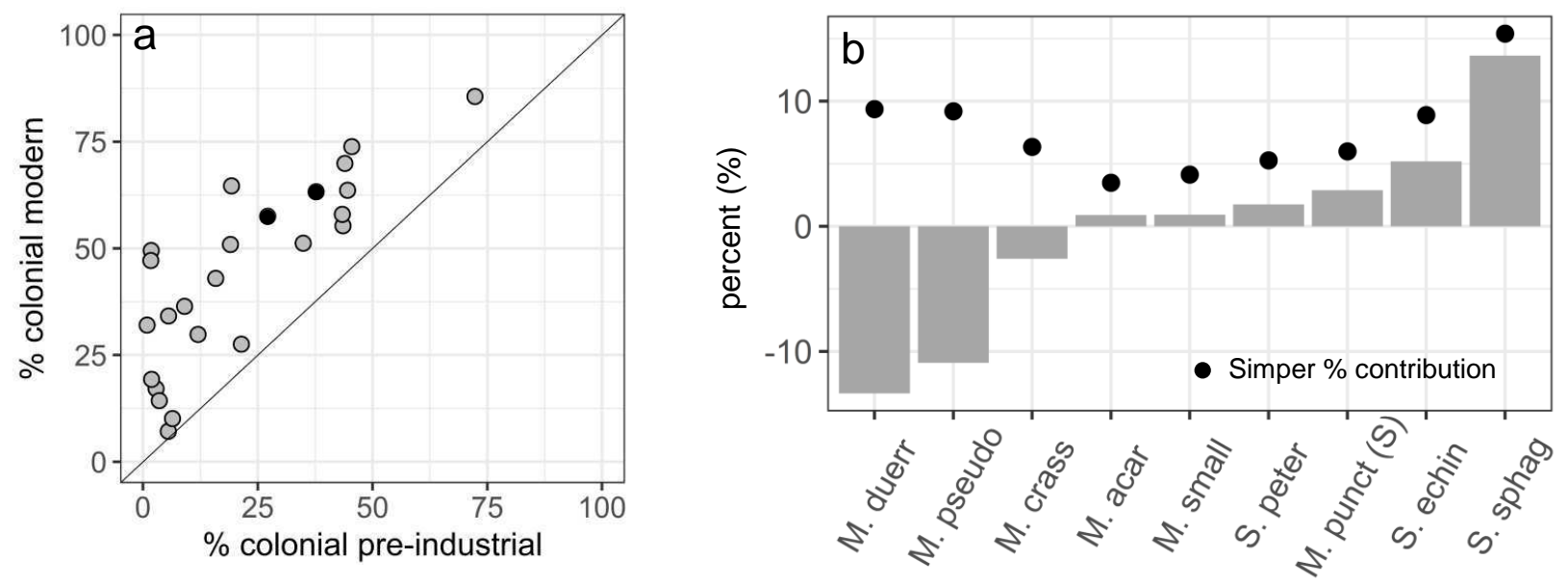

Fig. 4. 

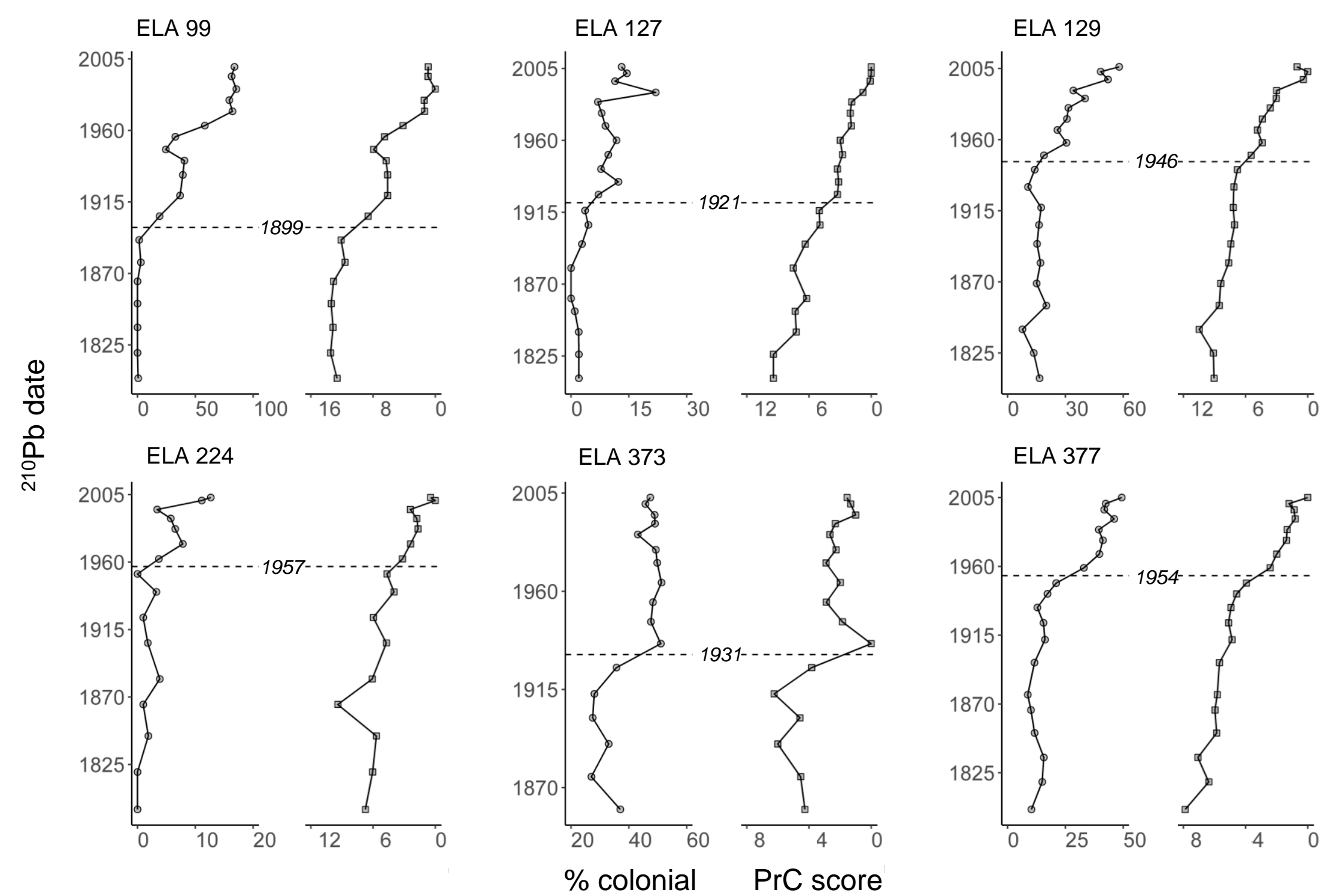

Fig. 5. 